\title{
PERAN SOSIAL PEREMPUAN DALAM \\ ISLAM: KAJIAN HISTORIS-NORMATIF \\ MASA NABI DAN KHULAFA' RASYIDUN
}

\author{
M. Hadi Masruri \\ Fakultas Tarbiyah UIN Maliki Malang \\ Email: hadimasruri@ymail.com \\ Telepon: 085855789998
}

\begin{abstract}
The debate on women's social role in Islam is an endless issue. What has been done by contemporary muslim thinkers to cover women issues is not enough to influence central feminism issue, gender equality and gender equity. It can be shown from the stereotype for women to limit women's social role only in domestic area still exists. The stereotype on women is based on the understanding religious doctrine which is inherited by previous generation and it is considered to have historical root in Prophet's tradition and His followers. This writing tries to prove that in the age of the Prophet and the age of khulafa ar Rasyidun can be the pilot project of social role of women historically as well as normatively. At least, women played significant role during that age in social, economics, and politics areas. All the facts of women's role are included within Qur'an and hadith and they are also released in classical history of Islam such as Tarikh alThabari and Thabaqat Ibn Sa'ad.
\end{abstract}

Perdebatan tentang peran sosial perempuan dalam Islam seolah tidak mengenal titik henti. Apa yang telah dilakukan para pioner pemikir Islam kontemporer untuk mengcover isu-isu tentang perempuan, belumlah cukup memberikan pengaruh terhadap isu sentral feminisme, yakni kesetaraan dan keadilan gender. Hal ini setidaknya dapat lihat dari masih adanya pandangan setereotip terhadap perempuan, terutama yang perempuan hanya pada ranah domestik. Hal itu didasarkan pada dogma agama yang mereka warisi secara turun temurun dan 'dipandang' mempunyai akar historis pada sunnah nabi Muhammad dan sesudahnya. Tulisan ini berupaya membuktikan bahwa masa nabi Muhammad dan Khulafa Rasyidun justru dapat menjadi sebuah pilot project bagi peran sosial 
wanita dalam Islam baik secara historis maupun normatif. Setidaknya, karena perempuan Islam pada masa ini memang memainkan peran sosial yang cukup signifikan, baik dalam ranah agama, sosial, ekonomi, dan politik. Fakta-fakta kesejarahan ini tidak hanya secara jelas terekam dalam sumbernya yang autentik, yakni al-Qur'an dan hadits nabi yang shahih, juga dirilis dalam referensi-referensi sejarah Islam klasik, seperti Tarikh al-Thabari dan Thabaqat Ibn Sa'ad.

Keywords: peran sosial, peran domestik, feminisme, egalitarianisme

\section{Pendahuluan}

Peran sosial perempuan terutama di ranah publik, hingga kini masih relevan dan menjadi perdebatan berbagai pihak, baik dalam frame feminisme global maupun dalam kerangka kajian pemikiran Islam (Islamic thaught). Setidaknya karena dua alasan: pertama, adanya keprihatinan yang mendalam terhadap realitas kecilnya peran perempuan dalam kehidupan sosial-ekonomi, apalagi politik dibandingkan dengan peran laki-laki (Ilyas, 2006: 1-2). Kedua, keinginan kalau bukan pemberontakan dari perempuan sendiri untuk memberdayakan dirinya, sehingga mampu memberikan kontribusi dan peran yang berarti untuk kehidupan dan kemanusiaan pada umumnya (Al-Marmissi, 1991).

Upaya penyetaran gender antara laki-laki dan perempuan yang diusung gerakan feminisme global, terutama pasca kolonialisme Barat atas dunia Islam, memberikan dampak yang cukup signifikan pada geliat feminisme di lingkungan masyarakat muslim. Hal ini tidak hanya mendorong para pemikir Islam kontemporer untuk melakukan pembacaan ulang ( $i$ 'adat al-qira'ah) melalui pendekatan dan metodologi modern yang dikenal sebagai pembacaan kontemporer (qira'ah mu'ashirah) terhadap tradisi dan khazanah Islam klasik tentang isu perempuan, melainkan turut melahirkan tokoh-tokoh feminis baru, di lingkungan dunia Islam, misalnya Fatima al-Marnissi (Marokko), Riffat Hassan (Pakistan), Amina Wadud Muhsin (Malaysia), Asghar Ali Engineer (India), dan sederet nama lainnya, yang kesemuanya mengusung isu-isu perempuan, seperti egaliterianisme, kesetaraan gender, hah-hak perempuan, penciptaan perempuan, perkawinan, dan peran sosial perempuan dalam perspektif ajaran Islam, terutama melalui sumber aslinya Al-Qur'an. 
Apa yang telah dilakukan para pioneer pemikir Islam kontemporer untuk mengkaver isu-isu tentang perempuan, yang kemudian diikuti oleh munculnya 'pemberontakan' yang diusung oleh para feminis muslim modern belumlah cukup memberikan pengaruh terhadap isu sentral feminisme, yakni egalitarianisme dan kesetaraan gender. Hal ini setidaknya dapat lihat dari pandangan setereotip terhadap perempuan, terutama yang membatasi peran sosial perempuan hanya dalam seputar keluarga masih menggejala sampai saat ini di dalam komunitas masyarakat muslim, seakan merupakan dogma agama yang diwarisi secara turun temurun dan 'dipandang' mempunyai akar historis pada tradisi (baca: sunnah) Nabi Muhammad dan sesudahnya (Laila Ahmed, 2000: 19).

Hampir di sepanjang sejarah peradaban manusia, perempuan hanya memainkan peran sosial, ekonomi apalagi politik yang kecil kalau dibandingkan dengan laki-laki. Sebaliknya peran domistik perempuanlah yang lebih menonjol, baik sebagai istri maupun ibu rumah tangga (Ilyas, 1997:1). Asghar Ali Engineer juga mendukung adanya dominasi laki-laki di sepanjang zaman, kecuali dalam masyarakat matriarkhal yang jumlahnya tidak seberapa, bahkan perempuan dipandang lebih rendah dari laki-laki (Engineer, 1994:55).

Tradisi yang memandang perempuan sebagai komunitas 'kelas dua' telah mengakar dalam sejarah kebudayaan Arab pra-Islam yang dikenal sebagai zaman Jahilyah. Kedudukan dan status sosial perempuan sangat tidak dihargai. Perempuan secara sosial, ekonomi, dan politik tidaklah bebas, dan tidak dapat memainkan peran yang independen yang dapat menunjukkan harkat dan setatusnya sebagai seorang perempuan. Dalam keluargapun perempuan terlihat lebih termarginalkan, hidup dengan suami yang mempunyai lebih dari dua belas istri. Perempuan dipandang sebagai beban hidup, bahkan di dalam banyak kasus ada usaha-usaha untuk mengubur anak perempuan hidup-hidup sebagaimana yang terekam dalam al-Qur'an: "Apabila bayi-bayi perempuan yang dikubur hiduphidup ditanya; karena dosa apakah dia dibunuh" (QS. At-Takwir, 81: 8-9) sebagaimana diliris al-Thabari (Al-thabari, 2000:248).

Pandangan serupa juga dikemukakan 'A'isyah Abd ar-Rahman (Bint asy-Syathi'), yang menjelaskan bagaimana pembunuhan terhadap anak perempuan sudah sedemikian membudaya di hampir semua kabilah 
bangsa Arab, meskipun ada yang tetap bertahan memelihara putrinya sampai dewasa dengan kesabaran dan ketahanan, kemudian dapat diserahkan kepada peminangnya yang sederajat, atau melilih kuburan sebagai “menantu" setianya (Bint asy-Syathi', 1992:69). Bahkan dalam struktur ekonomi masyarakat Arab Jahiliyah, perempuan diperdagangkan, bahkan juga diwariskan seperti harta benda dan kekayaan. Perempuan diperbudakkan di samping juga laki-laki, dan secara legal-formal budak perempuan yang dikenal sebagai amah atau jariyah harus melayani kebutuhan biologis tuannya, bahkan sudah menjadi tradisi para jariyah itu diganggu dan dijaili oleh setiap lelaki yang mendapatinya, sehingga perempuan hampir tidak lagi memiliki harkat dan martabat kemanusiaannya (Engineer, 2000:43).

Zaman awal Islam, terutama masa nabi Muhammad dan Khulafa Rasyidun, sebenarnya merupakan point penting dalam sejarah sosial perempuan. Setelah Islam datang, melalui sosok pribadi Muhammad sebagai nabi, terjadi perubahan yang luar biasa kalau tidak revolusioner, terutama pada kedudukan perempuan dan posisinya dalam struktur budaya masyarakat Arab. Banyak sisi kehidupan pribadi Muhammad dalam interaksinya dengan perempuan-perempuan di sekelilingnya, terutama dalam tataran sosial, politik dan keagamaan, yang jika ditelusuri merupakan sikap yang revolusioner di dalam upaya mengembalikan hak-hak perempuan pada proporsi yang semestinya. Khadijah, misalnya: adalah seorang perempuan yang independen. Setelah menikah dengan nabi, Khadijah tetap menjalankan bisnisnya berdagang, aktif berinteraksi dengan masyarakat dan mendukung sepenuhnya perjuangan nabi berdakwah kepada Islam. Khadijah adalah citra perempuan yang bebas, tegas dan tidak sesuai dengan 'anggapan' tentang perempuan pasif dalam masyarakat Islam. Khadijah dikenal tidak hanya sebagai istri nabi Muhammad SAW saja, melainkan juga ibu bagi orang-orang mukmin (umm al-mu'minin) (Ibn Sa'ad, 1990:130).

Demikian juga, masa setelah wafatnya sang nabi, merupakan masa transisi, yang justru perempuan mengambil peran sosial yang cukup signifikan dan menuntukan, bahkan dalam politik. Hal ini setidaknya tergambar dalam sikap 'Aisyah binti Abu Bakar yang menentang kekuasaan 'Ali ibn Abi Thalib dalam perang Jamal, dan posisinya sebagai referensi utama dalam urusan keagamaan, terutama yang terkait dengan urusan 
keperempuanan (Al-Afghani, tt). Demikian juga Hafsah binti 'Umar yang mempunyai peranan yang cukup signifikan dalam sejarah penghimpunan Al-Qur'an.

Kedua masa ini, sebenarnya dapat menjadi pilot project dari sebuah peran sosial perempuan dalam sejarah Islam yang panjang, karena masamasa setelahnya merupakan masa kekuasaan dinasti yang sarat dengan selir (dalam istana harem-nya) dan tradisi jariyah, yang kemudian peran sosial perempuan berangsur-angsur surut seiring dengan perluasan wilayah Islam dan dominasi tirani kekuasaan penguasa. Hal ini terus berlangsung hingga berabad-abad kemudian (Laila Ahmed, 2000:79-80).

Dari point ini, penelitian ini hendak mengkaji peran sosial perempuan di zaman awal Islam, terutama pada zaman nabi Muhammad s.a.w. dan masa Khulafa' rasyidun, sekaligus berupaya menganalis secara sosialhistoris faktor-faktor yang mendorong perempuan-perempuan muslim mengambil peran sosialnya, baik dalam agama, sosial, ekonomi, dan politik.

\section{Peran Sosial Perempuan di Masa Awal Islam (Nabi dan Khulafa' Rasyidun)}

Peran sosial perempuan sebenarnya dapat dilacak melalui konsep egalitarianisme antara laki-laki dan perempuan. Hal ini tidak hanya termaktub secara jelas dalam Al-Qur'an, melainkan lebih jauh lagi bahwa Al-Qur'an merupakan rekaman autentik terhadap peristiwa-peristiwa yang terjadi dalam sejarah, tertama tentang isu egaliterianime. Dalam beberapa ayat Al-Qur'an, perempuan diseru secara eksplisit bersama-sama dengan laki-laki dalam banyak peran sosial, misalnya:

"Sesungguhnya, laki-laki dan perempuan yang muslim, laki-laki dan perempuan yang mukmin, laki-laki dan perempuan yang tetap dalam ketaatannya, laki-laki dan perempuan yang benar, laki-laki dan perempuan yang sabar, laki-laki dan perempuan yang khusu', laki-laki dan perempuan yang bersedekah, laki-laki dan perempuan yang brpuasa, laki-laki dan perempuan yang memelihara kehormatannya, laki-laki dan perempuan yang banyak menyebut (nama) Allah, Allah telah menyediakan bagi mereka ampunan dan pahala yang besar; Dan tidaklah patut bagi laki-laki yang mukmin dan perempuan yang mukmin, apabila Allah dan rasul-Nya telah menetapkan suatu ketetapan, aka nada bagi mereka pilihan (yang 
lain) tentang urusan mereka. Dan barang siapa mendurhakai Allah dan rasul-Nya, sungguhlah dia telah sesat, sesat yang nyata" (QS. Al-Ahzab, 33: 35-36)

Ayat diatas merupakan pernyataan yang jelas dan tegas tentang identitas manusia secara bersama, baik laki-laki dan perempuan dalam berbagai kewajiban agama, sosial, spiritual dan etika yang identik tanpa memperdulikan jenis kelamin. Ayat lainnya juga menegaskan adanya prinsip egalitarianisme antara laki dan perempuan di dalam memperoleh pahala dari hasil kerja mereka: "sungguh Aku tidak menyia-nyiakan amal siapun yang beramal di antaramu, baik laki-laki maupun perempuan, karena sebagian kamu berasal dari sebagian yang lain" (QS. An-Nisa', 3:195). Bahkan di ayat yang lain, Al-Qur'an menyatakan bahwa perolehan pahala sesuai dengan kualitas dan kerja yang telah dilakukan baik oleh laki-laki maupun perempuan tanpa membedakan jenis kelamin:

"Dan janganlah kamu irihati terhadap apa yang dikaruniakan Allah kepada sebagian kamu lebih banyak dari sebagian yang lain, karena bagi orang laki-laki imbalan dari apa yang mereka usahakan, dan bagi peremuan juga imbalan dari apa yang mereka usahakan. Dan mohonlah dari Allah sebagaian dari karunia-Nya. Sesungguhnya Allah maha mengetahui segala sesuatu" (QS. AlMaidah, 4:32) (Al-thabari, 2000:264).

Sebagimana yang diceritakan Al-thabari, bahwa ayat-ayat tersebut di atas diturunkan karena dilatarbelakangi adanya peristiwa yang menggambarkan bagaimana para perempuan di zaman awal Islam tanpa segan aktif mengeluarkan pendapat mereka dan mempertayakan ketidakikutsertaan mereka pergi berperang sebagaimana para laki-laki. Meskipun sebelum itu menurut Al-thabari terjadi perdebatan diantara para laki-laki tentang tuntutan mereka agar diberikan pahala dua kali lipat dari pahala yang diperoleh kaum perempuan sebagaimana warisan, di mana laki-laki mendapatkan dua bagian perempuan (QS. An-Nisa', 4:11).

\section{Perempuan dan Sosial Keagamaan}

Beberapa literature sejarah Islam klasik, semisal Tarikh alThabari dan Thabaqat Ibn Sa'ad banyak merilis bagaimana perempuan dalam masyarakat Islam awal berperan aktif dalam kegiatan sosial kemasyarakatan. Para perempuan itu turut serta berbai'at kepada nabi 
Muhammad, berhijrah ke Madinah bersama kaum Muhajirin. Mereka mendatangi masjid, berperan dalam ibadah-ibadah keagamaan, harihari besar Islam dan mendengarkan ceramah-ceramah nabi Muhammad (Abu Syaqqah, 1995: 88). Ibn Sa'ad dalam Thabaqat-nya menceritakan bahwa mereka bukanlah pengikut dan pendengar yang pasif dan penurut, melainkan sebagai mitra bicara yang aktif dalam berbagai bidang agama dan persoalan-persoalan kehidupan (Ibn Sa'ad, 1990:278).

Beberapa riwayat hadis menggambarkan bagaimana perempuanperempuan berpartisipasi dalam dunia pemikiran Islam dan praktek keagamaan, mengomentari secara fair topik apapun, bahkan persoalan hubungannya dengan suaminya, sebagaimana yang terekam dalam Al-Qur'an: "Sesungguhnya Allah telah mendengar perkataan perempuan yang mengajukan gugatan kepada kamu tentang suaminya, dan mengadukan halnya kepada Allah. Dan Allah mendengar soal-jawab antara kamu berdua. Sesungguhnya Allah maha mendengar lagi maha melihat" (QS. Al-Mujadilah, 58:1) (Abu Syaqqah, 1995:96).

Al-thabari menceritakan bahwa perempuan tersebut adalah Khuwailah bint $\mathrm{S} \mid \mathrm{a}$ 'labah adalah seorang perempuan Anshar yang mengadu tentang suaminya Aus Ibn Al-Shamit yang telah mengatakan kepadanya “Anti kazhahri ummi”. Nabipun merespons positif 'aduan' Khuwailah dan terjadilah diskusi yang serius antara keduanya sampai turun ayat AlQur'an sebagai jawabannya: “Orang-orang yang menzhihar istri mereka, kemudian hendak menarik kembali apa yang mereka ucapkan, maka (wajib atasnya) memerdekaan seorang budak sebelum kedua suami-istri itu bercampur. Demikianlah yang diajarkan kepada kamu, dan Allah maha mengetahui apa yang kamu kerjakan" (QS. Al-Mujadilah, 58:3). Hal ini kemudian menimbulkan perdebatan di antara hali tafsir tentang hukum zhihar (Al-Thabari, 2000:220).

Satu persoalan lagi yang perlu diketengahkan di sini adalah sikap protes dan menuntut keadilaan yang ditunjukkan oleh para perempuan kepada nabi Muhammad adalah persoalan wacana (baca: khitab) dalam Al-Qur'an adalah mengapa Al-Qur'an hanya menyeru kaum pria dan pada saat yang sama para perempuan harus memenuhi seruan Allah dan rasul-Nya. Sikap protes ini juga dilatarbelakangi adanya pandangan dalam masyarakat Islam saat itu bahwa kaum pria mengungguli perempuan dalam 
hak-haknya, terutama pengetahuan agama, adalah hal yang mendorong para perempuan itu meminta kepada nabi Muhammad untuk memberikan waktu tambahan kepada mereka untuk mengajar mereka, sehingga dapat menyamai kaum pria. Bahkan menurut suatu riwayat diceritakan bahwa Umm Salamah mewakili kaumnya bertanya kepada nabi Muhammad: "kenapa kaum laki-laki selalu disebut di dalam Al-qur'an, dan kami para perempuan tidak demikian?”. Nabi-pun menunggu jawaban dari langit (Al-Thabari, 2000:270).

Suatu hari, ketika Umm Salamah menyisir rambutnya dengan santai, karena penasaran terhadap pertanyaannya yang belum dijawab oleh nabi karena masih menunggu jawaban dari langit, Umm Salamah mendengar nabi di dalam masjid membacakan ayat terakhir yang diwahyukan kepadanya sebagai jawaban terhadap pertanyaannya, sebagaimana diceritakan oleh Al-thabari: "Saya pernah bertanya kepada nabi Saw., mengapa Al-Qur' an tidak berbiacara tentang kami sebagaimana berbicara tentang kaum lakilaki. Dan alangkah terkejutnya diriku pada suatu siang, ketika saya tengah menyisir rambut, saya mendengar suara beliau dari mimbar. Saya dengan tergesa-gesa menyelesaikan sisiran saya dan lari ke salah satu kamar dimana dari situ saya bisa mendengar lebih baik. saya tempelkan telinga saya ke dinding..." dan nabi berkata membacakan ayat Al-qur'an surat alAhzab: "Wahai manusia, Allah berfirman dalam kitabnya: "Sesungguhnya, laki-laki dan perempuan yang muslim....” (QS. Al-Ahzab, 33: 35-36) (AlThabari, 2000:270).

Jawaban Allah terhadap pertanyaan Umm Salamah sangatlah jelas. Allah berbicara tentang dua jenis kelamin dalam hubungan kesetaraan gender yang menyeluruh sebagai komunitas yang beriman, yakni sebuah anggota komunitas sosial. Allah menggambarkan mereka sebagai bagian dari kerajaan-Nya, dimana mempunyai hak-hak yang sama untuk mendapatkan pahala-Nya yang besar. Dan bukan jenis kelamin (baca: berdasarkan gender) yang menentukan siapa yang akan mendapatkan rahmat-Nya, melainkan ketaatan dan keikhlasan untuk selalu mengabdi kepada-Nya. Ayat yang didengar Umm Salamah dapat dipandang sebagai deklarasi secara tegas terhadap hak-hak perempuan, sekaligus merupakan sikap yang revolusioner terhadap struktur budaya masyarakat Arab kala itu. 
Perhatian Umm Salamah yang begitu besar pada perempuan, yang terekam dalam pertanyaannya, sebenarnya tidak saja mencerminkan sikap pribadi seorang bangsawan Quraisy, melainkan bisa jadi merupakan pandangan umum kaum perempuan kota Madinah. Al-thabari menyakini, bahwa pertanyaan tersebut memiliki akar pada sebuah gerakan protes dari kaum perempuan Madinah. Pertanyaan itu muncul sebagai akibat desakan politis dan bukan lahir dari sebuah spontanitas dari seorang istri yang tercinta. Al-thabari menceritakan bahwa "sebagian perempuan datang kepada istri-istri rasulullah dan berkata: "Allah telah berbicara tentang kalian semua (istri-istri nabi) secara khusus di dalam Al-Qur'an, apakah tidak ada satupun tentang kami yang layak disebutkan?" (Al-Thabari, 2000:596).

Bukan saja kaum perempuan yang merasakan kepedulian Umm Salamah, tetapi lebih dari itu, mereka juga menyebabkan turunnya wahyu sebagai jawaban terhadap peristiwa yang telah terjadi, yakni sebuah penolakan terhadap tradisi masyarakat Jahilyah, dan mempertanyakan kebiasaan-kebiasaan yang mengatur hubungan antara laki-laki dan perempuan. Kaum perempuan saat itu beranggapan bahwa segala sesuatu dapat berubah dengan ajaran agama Islam, dan mereka berhasil. Hal itu setidaknya terbukti dengan adanya penggunaan sebuah surat di dalam AlQur'an dengan nama an-Nisa' (perempuan), yang memuat hukum-hukum baru tentang warisan, yang mengurangi hak-hak kaum lelaki. Laki-laki dan perempuan sama-sama mempunyai hak untuk mewarisi dan mewariskan, sama-sama mempunyai hak dalam pembagian harta warisan: "Bagi lakilaki ada hak bagian dari harta peninggalan ibu-bapak dan kerabatnya, dan bagi perempuan ada hak bagian (pula) dari harta peninggalan ibubapak dan kerabatnya, baik sedikit atau banyak menurut bagian yang telah ditetapkan" (QS. An-Nisa', 4:7).

Ayat di atas meskipun terlihat pendek, namun mempunyai pengaruh yang begitu kuat dan mendalam bagi penduduk kota Madinah saat itu. Untuk pertama kalinya perempuan dihadapkan pada persoalan yang menjawabnya ditetapkan langsung dari langit. Jauh sebelum ayat itu diturunkan, hanya kaum laki-laki yang mendapatkan hak waris dalam struktur budaya masyarakat Arab, dan kaum perempuan bahkan menjadi bagian dari harta yang diwariskan. 
Menurut al-Thabari bahwa ketika seorang laki-laki meninggal dunia, putra tertuanya mewarisi jandanya. Dia bisa mengawininya, jika bukan ibu kandungnya atau bisa memberikannya kepada saudaranya atau keponakan laki-lakinya. Dan jika dia sangat menginginkannya, maka dia dapat mengawininya untuk menggantikan tempat ayahnya (Al-Thabari, 2000:104).

Al-Thabari lebih lanjut menceritakan bahwa kaum perempuan Madinah menuntut diberlakukannya hukum baru yang mengatur soal warisan. Kabasyah bint Man'an misalnya telah melaporkan kepada nabi kejadian yang telah menimpa putra suaminya yang ingin mewarisi dirinya sesuai dengan tradisi yang berlaku di dalam masyarakat Arab Jahiliyah dengan berkata: "Wahai nabi, saya tidak mewarisi apapun dari suami saya atau memiliki kebebasan untuk menikah lagi dengan siapapun yang aku inginkan" (Al-Thabari, 2000:105). Abu Qais ibn al-Aslat putra suaminya itu menolak untuk menerapkan hukum baru tersebut dan bersikeras untuk mewarisi istri dari ayahnya.

Konflik antara laki-laki dan perempuan tersebut sekali lagi telah merisaukan dan memecah belah masyarakat. Dan kaum perempuanlah yang mendapatkan kemenangan. Allah telah mengabulkan tuntutan mereka, Abu Qais kehilangan hak prerogatif sebagai seorang lelaki yang hidup di tengah struktur budaya Arab Jahilyah. Allah secara tegas melarang tradisi mewariskan perempuan dalam kitabnya: "Hai orang-orang yang beriman, tidak halal bagi kamu untuk mewarisi perempuan secara paksa dan janganlah menyusahkan mereka karena hendak mengambil kembali sebagian dari apa yang telah kamu berikan kepadanya, kecuali mereka melakukan pekerjaan keji yang nyata. Dan pergaulilah mereka dengan baik. kemudian jika kamu tidak menyukai mereka, (maka bersabarlah) karena mungkin kamu tidak menyukai sesuatu, padahal Allah menjadikan padanya kebaikan yang banyak" (QS. An-Nisa', 4:19).

Dari penggalan kisah Al-Thabari ini sebenarnya dapat digaris bawahi, bahwa perempuan mempunyai peran yang cukup penting di dalam transformasi pemikiran Islam, bahkan pembentukan syariah Islam, terutama hukum waris sebagaimana tersebut di atas. Dan lebih dari itu bagaimana mereka berperan secara sosial dalam sebuah struktur budaya masyarakat Arab-Islam. 
Sepeninggal nabi Muhammad saw., para perempuan eks istriistri nabi terus memegang peranan yang cukup signifikan, terutama di dalam mentransformasikan ajaran Islam, terutama melalui transmisi hadis sebagaimana dikutip oleh Laila Ahmed (Laila Ahmed, 2000:89). 'Aisyah khususnya, bersama Umm Salamah dan Zaenab sebagai istri kedua adalah seorang ahli hadis yang penting. Semua sahabat mengakui bahwa ia secara khusus dekat dengan nabi Muhammad. Tidak beberapa lama setelah wafatnya nabi, masyarakatpun bertanya kepadanya tentang praktek kehidupan nabi Muhammad saw., riwayat-riwayat hadis yang disampaikannya berfungsi menyelesaikan berbagai persoalan masyarakat, bahkan persoalan hukum sekalipun. Misalnya saja, ketika Shafiyyah (wafat th. 670 M.), janda nabi Muhammad yang sebelumnya berasal dari kaum Yahudi, dan menginginkan agar sepertiga harta kekayaannya diserahkan kepada keponakannya, muncul perdebatan tentang apakah status agama Yahudi keponakannya membatalkan hak warisnya. Ketika ditanya, 'Aisyah menjawab bahwa keinginan itu haruslah dihormati. Bahkan yang lebih penting lagi adalah kesaksian 'Aisyah tentang cara nabi Muhammad saw. melakukan shalat atau cara membaca sebuah ayat Al-Qur'an dalam menyelesaikan berbagai persoalaan tentang shalat dan bacaan Al-Qur'an yang benar. Ibn Sa'ad menyebut 'Aisyah sebagai manausia paling alim karena menjadi rujukan para ulama sepeninggal nabi Muhammad saw. Mereka bertanya kepadanya tentang berbagai persoalaan agama (fatwa), periwayatan hadis dan fiqih (Ibn Sa'ad, 1990:378). Bahkan Laila Ahmed mengutip bahwa 'Aisyah sebagai ahli hadis telah meriwayatkan hadis kepada beberapa ahli hadis kurun awal, dan ada sekitar 2.210 hadis dinisbatkan kepadanya. Imam al-Bukhari dan Muslim, yang dikenal sangat ketat menetapkan standara periwayatan hadis meriwayatkan di dalam Shahih merereka sekitar 300 hadis yang dinisbatkan kepada 'Aisyah (Laila Ahmed, 2000:89).

Kondisi ini terus berlanjut di masa kekhalifahan Khulafa' Rasyidun. 'Aisyah dan Hafshah, sebagai putri-putri dari dua khalifah pertama, Abu Bakar dan 'Umar ibn Khaththab, memiliki prestise dan pengaruh yang besar. Baik Abu Bakar maupun 'Umar ibn Khaththab, sebelum wafatnya memberikan kepada putra-putrinya berbagai tanggung jawab penting. Abu Bakar misalnya, menjelang wafatnya memberi 'Aisyah tanggung jawab 
mengatur dana dan kekayaan publik dan membagi-bagikan kekayaannya kepada putra-putrinya yang tengah tumbuh dewasa. Sewaktu 'Umar ibn Khaththab wafat, salinan naskah Al-Qur'an, yang sebelumnya di tangan Abu Bakar dan kemudian dipegang 'Umar ibn Khaththab, dipercayakan kepada Hafshah untuk disimpan (Ibn Sa'ad, 1990:195).

\section{Perempuan dan Politik}

Politik merupakan salah satu peran penting yang dimainkan para perempuan Islam di masa awal, bahkan di masa pra-Islam sekalipun. Dalam perang misalnya para perempuan itu hadir di medan perang, terutama untuk merawat orang-orang yang terluka dan membakar semangat kaum pria dengan lagu dan syair. Sejumlah perempuan menjadi terkenal karena syair-syair mereka yang mendorong para prajurit untuk bertempur lebih semangat lagi, dengan mengecam kematian, kekalahan, atau merayakan kemenangan. Dalam perang Uhud misalnya, Umm Umarah dikenal turut serta dalam perang yang dahsyat itu bersama suami dan anak-anaknya (Al-Thabari, 2000:562). keberanian dan kemahirannya dalam memainkan senjata menjadikan nabi Muhammad mengetahui bahwa Umm Umarah lebih hebat dari kebanyakan pria. Umm Umarah terus ikut berperang dalam berbagai peperangan kaum Muslimin, sampai kehilangan tangannya dalam peristiwa 'Uqrabah (634 M.) (Ibn Sa'ad, 1990:429).

Ibn Sa'ad juga mencatat dalam sejarah peperangan kaum Muslimin sesudah wafatnya nabi Muhammad saw., nama-nama prajurit perempuan luar biasa lainnya, misalnya Umm Hakim bint Al-Harits yang dengan satu tangannya mengalahkan tujuh prajurit Romawi dalam pertempuran di Marj al-Shaffar, yang saat itu baru dinikahi oleh Khalid ibn Sa'id dekat sebuah jembatan di al-Shaffar, sehingga dikenal dengan 'Jembatan Umm Hakim'. Umm Hakim yang masih pengatin baru ini bertempur dengan gigih dan berani tanpa panah, tombak maupun pedang, ia bertempur dengan sepotong tiang penyangga tenda yang digunakan saat pernikahannya. Bahkan suaminya Khalid ibn Sa'id meninggal dalam pertempuran itu (Ibn Sa'ad, 1990:99).

Begitu juga dalam perang Yarmuk, sebagaimana dirilis dalam Tarikh al-Thabari (Al-Thabari, 2000: 338) terdapat sekelompok perempuan bertempur sangat hebat dalam peperangan tersebut. Termasuk di dalamnya putri Abu Sufyan Juwairiyah beserta ibunya Hindun bint 'Uqbah yang 
telah memeluk Islam dan menjadi ibu Gubernur Syam, yang dalam perang Uhud menjadi panglima perang pihak lawan Islam, di mana telah merobek jantung Hamzah dan memakan hatinya. Dalam perang Yarmuk, Hindun menonjol dalam peperangan itu, membakar semangat kaum Muslimin dengan seruan: "Gempurlah orang-orang tak berkhitan itu dengan pedangpedang kalian!”. Diriwayatkan juga dari Al-Rabi‘ bint Mu'awwidz berkata: "Kami para perempuan ikut berperang bersama nabi Muhammad saw., kami memberi minum para tentara dan merawat mereka, kami menghantar para suhada dan para korban luka ke kota" (HR. Al-Bukhari). Dan Umm 'Athiyyah al-Anshariyyah berkata: "Saya turut serta bersama rasul saw. dalam tujuh peperangan, selalu mengikuti kemanapun mereka pergi, saya menghidangkan makanan, mengobati yang terluka dan merawat yang sakit" (HR. Muslim) (Abu Syaqqah, 1995:126).

Ketokohan 'Aisyah sebagai janda nabi Muhammad dalam arena politik tidak diragukan lagi. 'Aisyah tidak hanya sebagai rujukan para pembesar Islam kala itu dalam berbagai persoalan agama. Ia juga tampil sebagai tokoh politik yang sangat menentukan, terutama sepeninggal Utsman ibn 'Affan. 'Aisyah aktif menghimpun dukungan menetang suksesi 'Ali ibn Abi Thalib. 'Aisyah tampil di depan masjid di Makkah, sambil mengenakan hijab berpidato menentang 'Ali ibn 'Abi Thalib. Kontroversi tentang suksesinya akhirnya melahirkan perpecahan antara kaum muslimin, yang kemudian mencapai puncaknya dalam perang Unta (Mauqi 'at al-Jamal). 'Aisyah sendiri yang meanjadi panglima perang, mengatur siasat dan memimpin pertempuran (Al-Thabari, 2000:11).

Menyadari posisi 'Aisyah yang penting, 'Ali ibn Abi Thalib melumpuhkan untanya dan mencerai-beraikan pasukannya. 'Ali ibn Abi Thaliblah yang kemudian memenangkan pertempuran dan menjadi khalifah keempat (th. 656-661 M.). Meskipun demikian, 'Ali ibn Abi Thalib tetap memperlakukan 'Aisyah dengan baik. Peran penting yang dimainkannya dalam perang Jamal yang kontroversial ini, di mana ummat Islam untuk pertama kalinya saling menumpahkan darah sesama saudaranya sendiri, tentu dikecam banyak orang. Diantara sebabnya karena 'Aisyah dipadang telah melanggar hijab yang telah ditetapkan oleh nabi Muhammad, yang telah memerintahkan istri-istrinya tinggal dirumah sebagaimana perintah Allah dalam Al-Qur'an: 
"Hai istri-istri nabi, kamu sekalian tidaklah seperti perempuan lain. Jika kamu bertaqwa, maka janganlah tunduk dalam bebbicara berkeinginanlah orang yang ada penyakit dalam hatinya, dan ucapkanlah perkataan yang baik. Dan hendaklah kamu tetap tinggal di rumahmu dan jangalah kamu berhias dan bertingkah laku seperti orang-orang Jahilyah dulu. Dan dirikanlah shalat, tunaikanlah zakat, dan taatilah Allah dan rasul-Nya. Sesungguhnya Allah bermaksud menghilangkan dosa dari kamu wahai ahl al-bait dan membersihkan kamu sebersih-bersihnya" (QS. Al-Ahzab, 33:33-34).

Kalau tidak karena kekalahan 'Aisyah dalam perang Jamal tersebut, niscaya dapat setidaknya meminimalisir kecaman. Betapapun kacau balaunya kondisi politik saat itu, ummat Islam memang sebenarnya dihadapkan pada dua kubu kepentingan dalam suksesi kepemimpinan: kepentingan bani Hasyim yang terwakili oleh kelompok 'Ali ibn Abi Thalib dan kepentingan bani Umayyah di mana Utsman ibn 'Affan terbunuh (Faudah, 1986:39). Lepas dari kepentingan ini, yang penting untuk digarisbawahi dalam konteks kajian ini adalah 'Aisyah sebagai figur perempuan Islam masa awal peran yang cukup sentral dalam persoalan sosial, politik, dan agama.

\section{Peran Sosial Perempuan dalam Diskursus Kajian Keislaman}

Peran sosial yang dimainkan para perempuan Islam kurun awal sebagaimana dipaparkan di atas, sedikit banyak telah juga menjadi perdebatan para ulama, terutama di dalam menafsirkan ayat-ayat Al-Qur'an yang telah merekam beberapa poin penting tentang peraan aktif perempuan di masa awal Islam dalam berbagai sektor kehidupan, keluarga, agama, politik dan sosial.

Dalam konteks feminisme, peran sosial dikenal dengan peran domestik dan publik. Peran domestik dimaksudkan sebagai peran perempuan dalam keluarga atau rumah tangga, baik sebagai istri maupun ibu. Sedangkan peran publik diartikan sebagai peran perempuan dalam masyarakat, baik dalam rangka mencari nafkah, maupun untuk aktualisasi diri dalam berbagai aspek kehidupan: sosial, politik, ekonomi, pendidikan, dakwah dan lain sebagainya.

Sebagaimana dalam sejarah awal Islam, dalam Al-Qur' an terdapat beberapa ayat yang menggambarkan perempuan mempunyai peluang yang sama dengan laki-laki untuk berperan dalam sektor publik, misalnya: 
"Barangsiapayang mengerjakan amalsaleh, baiklaki-lakimaupun perempuan dalam keadaan beriman, maka sesungguhnya akan Kami berikan kepadanya kehidupan yang baik dan sesungguhnya akan Kami beri balasan kepada mereka dengan pahala yang lebih baik dari apa yang telah mereka kerjakan” (QS. Al-Nahl, 16:97).

Dalam ayat ini jelaslah, bahwa Allah memberi peluang dan menghargai secara sama antara laki-laki dan perempuan untuk melakukan amal saleh. Amal saleh tentu saja tidak terbatas pada pekerjaan-pekerjaan yang bersifat domestik, melainkan juga sosial dan publik. Bahkan dalam surat al-Taubah terdapat penegasan bahwa perempuan beriman saling tolongmenolong, bahu-membahu dengan laki-laki beriman dalam rangka amar ma'ruf dan nahi mungkar, akan mendapatkan rahmat (karunia) Allah:

"Dan orang-orang yang beriman, laki-laki dan perempuan, sebagaian mereka (adalah) menjadi penolong bagi sebagian yang lain. Mereka menyuruh (mengerjakan) yang ma'ruf, mencegah dari yang mungkar, mendirikan shalat, menunaikan zakat, dan mereka ta'at kepada Allah dan rasul-Nya. Mereka itu akan diberi rahmat oleh Allah. Sesungguhnya Allah Maha Perkasa lagi Maha Bijaksana" (QS. Al-Taubah, 9:71).

Amar ma'ruf dan nahi munkar dalam ayat di atas merupakan kegiatan berdakwah, yang sekalipun dapat dilakukan di rumah, tetapi tidaklah terbatas dalam rumah tangga semata, melainkan juga di dalam masyarakat sosial secara lebih luas. Bahkan lebih jauh dari itu dalam AlQur'an terdapat isyarat kemampuan perempuan dalam memimpin sebuah negara. Al-Qur'an menceritakan ratu Balqis yang memerintah negeri Saba' sebagai berikut:

"Maka tidak lama kemudian (datanglah Hud Hud), lalu berkata: "Aku telah mengetahui sesuatu yang kamu belum mengetahuinya; dan kubawa kamu kepadamu dari negeri Saba'suatu berita penting yang diyakini. Sesungguhnya kau menjumpai seorang perempuan yang memerintah mereka, dan dia dianugerahi segala sesuatu serta mempunyai singgasana yang besar" (QS. Al-Naml, 27:22-23)

Di ayat yang lain Al-Qur'an juga menggambarkan bagaimana perempuan, dalam hal ini putri-putri Nabi Syu'aib yang menggembalakan kambing-kambingnya, dan di saat mereka menunggu giliran untuk mem- 
beri minum ternak mereka di sutu sumber air Madyan, datanglah Musa menawarkan jasa kepada mereka sebagai berikut:

"Dan tatkala ia sampai di sumber air negeri Madyan, ia menjumpai sekumpulan orang yang sedang meminumkan ternaknya, dan ia menjumpai di belakang orang banyak itu itu, dua orang perempuan yang sedang menghambat (ternaknya). Musa berkata: "Apakah maksudmu (dengan berbuat begtitu)?". Kedua perempuan itu menjawab: "Kami tidak dapat meminumkan (ternakkami), sebelum penggembala-penggembala itu memulangkan (ternaknya), sedang bapak kami adalah orang tua yang telah lanjut umurnya" (QS. Al-Qashash, 28:23).

Dari sini, sebenarnya dapat digarisbawahi bahwa perekaman AlQur'an terhadap peran sosial yang dimainkan perempuan tidak hanya menujukkan 'boleh' (ibahah) secara normatif dilihat dari legal form syariah Islam, melainkan hal itu justru merupakan 'anjuran' agar perempuan Islam dapat perperan aktif dalam kehidupan sosial bermasyarakat sesuai dengan kemampuan (dalam bahasa Al-Qur'an: 'amal shalih\}) yang dimilikinya, sehingga perempuan mampu memberikan kontribusi yang berarti untuk kemajuan kehidupan dan menjadikan hidupnya lebih bermakna. Problem publikisasi peran perempuan baru muncul tatkala ada beberapa ayat AlQur'an yang dapat 'dimaknai' sebagai pembatasan diskriminatif terhadap perempuan (Ilyas, 1988:172). Misalnya dalam surat al-Ahzab:

"Dan hendaklah kamu tetap tinggal di rumahmu, dan janganlah kamu berhias dan bertingkah laku seperti orang-orang Jahilyah yang dahulu, dan dirikanlah shalat, tunaikanlah zakat, dan taatilah Allah dan rasul-Nya. Sesungguhnya Allah bermaksud hendak menghilangkan dosa dari kamu, hai ahl al-bait dan membersihkan kamu sebersih-bersihnya". (QS. Al-Ahzab, 33:33)

Ayat ini sering dimaknai sebagai perintah kepada para perempuan muslim agar tinggal di rumah, dan tidak meninggalkan rumahnya kecuali atas izin suaminya. Pemahaman model ini misalnya dipegangi oleh Ibn Katsir (Ibn Katsir, tt:406). Menurut Ibn Katsir ayat tersebut bukan saja perintah kepada istri-istri nabi melainkan juga kepada semua perempuan muslim (nisa'al-ummah) agar tetap berada di rumah, kecuali ada keperluan (fala takhrujna lighair hajat). Keperluan yang dibenarkan syariah Islam (hawa ij syar 'iyyah), contohnya shalat berjama'ah di masjid, berdasarkan 
hadis nabi Muhammad yang menyatakan jangan melarang hamba-hamba Allah perempuan (ima') untuk pergi ke masjid-masjid Allah. Bahkan dalam suatu riwayat disebutkan bahwa shalat di rumah lebih baik bagi mereka "wa buyutahunna khair lahunna".

Memperkuat argumen bahwa perempuan tetap berada dirumah lebih baik dari pada keluar rumah, Ibn Katsir juga mengutip sebuah hadis yang diriwayatkan oleh Abu Bakar al-Bazzar bahwa "Kami perempuanperempuan datang bertanya kepada rasulullah:

"Wahai rasulullah, kaum laki-laki mendapatkan keutamaan dengan berjihad di jalan Allah, lalu apa yang dapat kami kerjakan agar dapat mencapai derajat para mujahid di jalan Allah?” Rasul Allah menjawab: "Barang siapa di antara kalian yang duduk atau kalimat semacamnya di rumahnya, maka dia telah mencapai derajat para mujahid di jalan Allah" (HR. oleh Anas ibn Malik).

Tidak hanya Ibn Katsir yang berpandangan perempuan hanya 'boleh' berperan domestik, melainkan juga al-Alusi dalam tafsirnya Ruh alMa 'ani, tetapi juga al-Maraghi dalam Tafsir al-Maraghi, yang memandang ayat 33 dalam surat al-Ahzab tidak hanya ditujukan kepada istri-istri nabi Muhammad, tetapi juga semua perempuan muslim lainnya. Mereka tidak boleh keluar rumah, kalau tidak ada keperluan. Untuk memperkuat pemahaman ini para ahli tafsir ini juga mengutip hadis yang diriwayatkan oleh al-Bazzar dari at-Turmudzi bahwa nabi Muhammad mengatakan: "Sesungguhnya perempuan itu aurat. Dan jika keluar dari rumahnya, syaitan akan memuliakannya. Tempat yang paling dekat dengan rahmat Tuhannya bagi perempuan adalah di bagian dalam dari rumahnya" Ibn Katsir, tt:409).

Berbeda dengan ketiga mufassir di atas, al-Thabari, azZamakhsyari, dan al-Razi memandang ayat tersebut, sebagaimana ayatayat sebelumnya, hanya ditujukan kepada istri-istri nabi Muhammad saw. dan tidak mempunyai implikasi apapun terhadap perempuan muslimah lainnya. Pesan-pesan untuk para istri nabi itu sudah dimulai dari ayat 28 dari surat yang sama dengan kalimat "Wahai nabi, katakanlah kepada para istri-istrimu.....". Allah memerintahkan kepada para istri nabi untuk tetap di rumah, dan tidak berhias dan bertingkah laku seperti orang-orang Jahilyah dahulu, juga melarang untuk berbicara dengan sikap yang menimbulkan keberanian orang bertindak yang tidak baik kepada mereka. Sebab sikap 
berbicara seperti itu bisa mengundang keinginan laki-laki yang di hati mereka ada keinginan berbuat serong. Di samping merupakan dosa besar, tentu akan menjadi skandal besar, jika sampai terjadi hubungan yang tidak benar antara istri nabi dengan para sahabat nabi. Apalagi para istri nabi telah diangkat menjadi ibu bagi semua orang beriman (umm al-mu'minin) (Al-Thabari, 2000:259).

Di antara argumen mereka di dalam memahami ayat tersebut dikhususkan bagi nabi adalah pernyataan Al-Qur'an sendiri yang memandang mereka para istri nabi berbeda dari perempuan mslimah lainnya (lastunna ka ahadin min an-nisa'), di samping memang Allah hendak menghilangkan noda dari mereka dan membersihkan keluarga nabi Muhammad (ahl al-bayt) sebersih-bersihnya (Al-Thabari, 2000). Lebih dari itu, menurut al-Thabari bahwa rentetan ayat perintah tetap tinggal di rumah bagi istri nabi tersebut, diawali dari ayat 28, di mana 'Aisyah menuntut nafaqah yang lebih sebagai seorang istri nabi, yang kemudian membuat nabi Muhammad merajuk terhadap semua istri hampir sebulan, adalah hal yang kemudian menjadikan para istri nabi sedikit meninggikan suara, sehingga turunlah ayat yang melarang meninggikan suara "fala takhdla'na bi al-qaul" (Al-Thabari, 2000:253-257).

\section{Penutup}

Dari kajian di atas tentang historisitas dan normatifitas peran sosial perempuan di zaman awal Islam, meskipun hanya sepintas lalu, dapatlah ditarik sebuah benang merah, bahwa perempuan Islam dalam sejarah awal Islam memang memainkan peran sosial yang cukup signifikan, baik dalam ranah agama, sosial, ekonomi, dan politik. Fakta-fakta kesejarahan ini secara jelas terekam dalam sumbernya yang autentik, yakni Al-Qur'an dan hadis nabi yang valid (shahih), di mana menyertai peristiwa terjadi, serta dirilis dalam referensi-referensi sejarah Islam klasik, semisal al-Thabari dan Ibn Sa'ad.

Peran sosial yang dimainkan para perempuan muslimah kurun awal ini, kalau dilihat dari perspektif teori sosial, tentu didorong oleh beragam kepentingan. Di antaranya adalah pengakuan status sosial, agama, dan ekonomi. Uforia tentang datangnya agama baru yang dikenal dengan nama Islam ini telah memberikan nuansa dan angin baru bagi kehidupan masyarakat Arab abad ke tujuh, termasuk komunitas perempuannya untuk 
mendalami agamanya, sehingga mereka terdorong untuk aktif berperan dan memberikan andil bagi agama dan masyarakatnya sebagaimana perkataan nabi: "Khair al-nas anfa 'uhum li an-nas" (HR. Al-Baihaqi dan al-Thabrani) (Al-Albani, tt:560).

Lebih dari itu, kedudukan perempuan di zaman pra-Islam sebagaimana diuraikan pada kajian di muka, yang telah lama terkungkung oleh aturan tradisi Jahilyah, telah pula mendapatkan angin baru untuk mengaktualisasi diri dan menunjukkan eksistensinya terutama dalam tatanan masyarakat baru, sehingga mereka berbondong-bondong berbai' at kepada nabi, ikut perperang dan mengambil harta rampasan. Dari sini, faktor ekonomi sering menjadi pemicu adanya sebuah interaksi sosial, hal ini juga bisa dilihat bagimana para istri nabi yang dimotori oleh 'Aishah menuntut nafaqah yang lebih dari seorang laki-laki yang menjadi suaminya. Kalau bukan karena itu ayat-ayat yang termaktub dalam surat al-Ahzab di atas barangkali tidak akan pernah turun.

Peran sosial perempuan di masa awal Islam yang terekam dalam referensi utama sejarah Islam klasik ini, sudah semestinya menjadi pilot project dan landasan bagi sebuah legal form syariah Islam. Jadi, Persoalan egalitarianism dalam peran sosial antara laki-laki dan perempuan tidak perlu lagi diperdebatkan, melainkan keduanya diberi kesempatan yang sama untuk mengaktualisasi diri dan memberikan kontribusi yang berarti pada kemanusiaan. Kemampuan dan kelayakanlah yang menentukan, sehingga kehidupan akan menjadi lebih bermakna. Wallah a lam bi alShawab.

\section{DAFTAR PUSTAKA}

'Abd ar-Rahman, 'Aisyah. Putri-putri Nabi. Terj. Abdul Kadir Mahdamy. Solo: Pustaka Mantiq, 1992.

Abu Syaqqah, 'Abd al-Halim Muhammad. Tahrir al-Mar'ah fi 'Ahr arRisalah: Dirasah 'An al-Mar'ah Jami'ah li Nushushal-Qu'ran wa Shahihai al-Bukhari wa Muslim. Kuwait: Dar al-Qalam, 1995.

Al-Afghani, Sa'id. Pemimpin Perempuan di Kancah Politik: Studi Sejarah Pemerintahan 'Aisyah ('Aisyah wa Siyasah). Terj. Moch. Syarifuddin. Yogyakarta: Pustaka Pelajar, tt. 
Al-Halwani, Aba Firdaus. Perempuan-perempuan Pendamping Rosulullah. Yogyakarta: Al-Mahalli Press, 1996.

Al-Husaini, al-Hamidi. Baitun Nubuwwah: Rumah Tangga Nabi Muhammad Saw. Bandung: Yayasan Al-Hamidy, 1997.

Al-Jada', Ahmad. Nisa' Haula ar-Rasul. Mesir: Dar al-Basyir, 1997.

Al-Marnisi, Fathimah. Al-Harim al-Siyasi: an-Nabi wa an-Nisa', Tarj. Abd al-Hadi 'Abbas. Damaskus: Dar al-Hashad. tt.

Armstrong, Karen. Islam Sejarah Singkat (Islam: A Short History). Terj. Fungky kusnaedy Timur. Yogyakarta: Penerbit Jendela, 2002.

Arnold, Thomas W. The Preaching of Islam: A History of Propagation of The Muslim Faith. New Delhi: Low Price Publication 1995.

Al-Thabari, Muhammad ibn Jarir. Tarikh al-Umam wa al-Muluk (Tarikh al-Thabari). Bairut: Dar al-Kutub al-'Islamiyyah, 1407. http:// www.shamila.com.

Az-Zahabi. Tarikh al-Islam. http://www.alwarraq.com dalam Maktabah Shamilah http://www.shamila.com.

Barlas, Asma. Believing Women in Islam. London: Oxford University Press, 2003.

Bek, Muhammad Hudlari. Muhadlarat Tarikh al-Umam al-Islamiyyah. Kairo: Al-Maktabah al-Kubra, 1970.

Engineer, Asghar Ali. Hak-hak Perempuan dalam Islam. Terj. Farid Wajidi dan Cici Farkha Assegaf. Yogyakarta: Yayasan Bentang Budaya, 1994.

Fa:dah, Faraj. Al-Haqaiq al-Ghaibah. Kairo: 1986.

Fisrt Encyclopedia of Islam. Tt. Vol. 7. London: E.J. Brill.

Goldschmidt, Arthur Jr. A Concise History of Midle East. Colorado: Westview Press, 1983.

Hasan, Ibrahim Hasan. Tarikh al-Islam as-Siyasi wa ad-Dini wa al-tsaaqafi wa al-Ijtima ' $i$. Bairut: Dar al-Jail, tt.

Ibn al-Atsir. Al-Kamil fi at-Tarikh. http://www.shamila.com. 
Ibn Hisyam. Sirah Ibn Hisyam. Maktabah Syamilah. http://www.shamila. com.

Ibn Kastsir. Al-Bidayah wa an-Nihayah. Bairut: Maktabat al-Ma'arif. tt.

Ibn Sa'ad, Muhammad. Al-Thabaqat al-Kubra. Beirut: Dar al-Kutub al'Ilmiyyah, 1990. http://www.shamila.com.

Ilyas, Yunahar. Feminisme dalam Kajian Tafsir al-Qur'an Klasik dan Kontemporer. Yogyakarta: Pustaka Pelajar, 1988.

Waddy, Charis. Perempuan dalam Sejarah Islam (Women in Muslim History. Terj. Faruk Zabidi. Jakarta: Pustaka Jaya, 1987.

Wadud, Amina. Qur'an Menurut Perempuan: Membaca Kembali Kitab Suci dengan Semangat Keadilan. terj. Abdullah Ali. Jakarta: serambi, 2006.

------. Ahlam al-Nisa': Thufulah fi al-Harim. Tarj. Shayyah al-Juhayyim. Bairut: Dar 'Athiyah li al-Nasyr, 1997.

-------. Pemberontakan Perempuan: Peran Intelektual Kaum Perempuan dalam Sejarah Muslim. Terj. Rahmani Astuti. Bandung: Mizan, 1999.

-------. Ratu-Ratu Islam yang Terlupakan. Terj. Rahmani Astuti dan Erna Hadi. Bandung: Mizan, 1994.

------. Al-Jins ka-Handasah Ijtima iyyah Bain an-Nashsh wa al-Waqi", Tarj. Fathima az-Zahra' Zaryul. Bairut: al-Markaz al-Tsaqafi al'Arabi, 1996.

------. Islam dan Teologi Pembebasan. Terj. Agung Prihantoro. Yogyakarta: Pustaka Pelajar, 2000.

------. Jami al-Bayan fi Ta'wil al-Qur'an (Tafsir al-Thabari). TT.: Muassasat al-Risalah, 2000. http://www.shamila.com.

-------. Kesetaraan Gender dalam Al-Qur'an: Studi Pemikiran Para Mufasir. Jogjakarta: Labda Press, 2006.

------. Purnama Madinah. Terj. Eva Y. Nukman. Bandung: Penerbit AlBayan, 1997. 